\title{
REDESCRIPTION OF THE TAIL AND FIN FOLDS OF ECHINOSTOMA REVOLUTUM CERCARIAE FROM ITS TYPE LOCALITY (TREMATODA : ECHINOSTOMATIDAE)
}

\author{
I. KANEV ${ }^{1}$, U. EISENHUT ${ }^{*}$, M. OSTROWSKI DE NUNEZ**, M. Y. MANGA GONZALEZ***, \\ D. TZOLOV, V. DIMITROV, V. RADEV
}

\begin{abstract}
SUMMARY
From its type locality in Germany, Echinostoma revolutum (Froelich, 1802) Dietz, 1909 have cercariae with long cylindrical tails, and typical slender finger-like tips. The tail surface bears seven independent fin folds arranged in three pairs: proximal dorso-

ventral, distal dorso-ventral and ventro-lateral pairs, plus a single small papilla-like fold. Previous descriptions are inadequate due to incorrect interpretations or incomlete descriptions of the nature of the cercarial fin folds.
\end{abstract}

RÉSUMÉ: Queue et nageoires caudales de la cercaire d'Echinostoma revolutum (Trematoda: Echinostomatidae) dans la localité type.

Dans sa localité type, la queue de la cercaire d'Echinostoma revolutum est longue, cylindrique, avec une longue pointe digitiforme. Elle porte sept nageoires caudales indépendantes : une paire proximale dorso-ventrale, une paire distale ventro-dorsale, une paire distale ventro-latérale et un pli impair papilliforme. Les descriptions antérieures sont fausses par suite d'erreurs de descriptions ou d'erreurs de détermination.

\section{INTRODUCTION}

Cercariae identified as Echinostoma revolutum (Froelich, 1802) Dietz, 1909 have been described with different shapes and sizes of tails, bearing different numbers and arrangements of fin folds. These differences are: no fin folds on the tail surface (Johnson, 1920), only one very short fold, located dorsally on the posterior half of the tail (Beaver, 1937), two small dorso-ventral fin folds in the second half of the tail (Kosupko, 1972), one long and one short fold (Odening, 1964), two long folds which cover all dorsal and ventral surfaces of the tail except the tip (Balusek and Vojtek, 1973), two very long fin folds which cover the tail tip (Zdarska, 1963), four fin folds variable in size and position (Moravec et al., 1974), and seven fin folds (Nasincova, 1986). In addition, Johnson (1920) described the tail as having a conical tip and Beaver (1937) described it as

Institute of Parasitology, Bulgarian Academy of Sciences, B1.25, Sofia 1113, Bulgaria.

* Institute of Zoology, University of Erlangen, Erlangen D-8520, Germany.

** National Scientific and Research Counsil, Calcango 642, 1609 Boulogne, Argentina.

*** Scientific Research Counsil, Aptdo., 788, 24080 Leon, Spain.

1) Present address: Harold W. Manter Laboratory of Parasitology, Nebraska Hall W-529, Nebraska State Museum, University of Nebraska, Nebraska 68588-0547, USA.

Accepté le : 8 janvier 1993. a slender finger-like tip. These descriptions are too different in regard to fin-fold structures to belong to a single species and are thus problematic. To settle these problems, $E$. revolutum cercariae were examined from its type locality.

\section{MATERIALS AND METHODS}

Cercariae of $E$. revolutum were obtained from Lymnaea stagnalis (Linnaeus, 1758) collected in the same place near Erlangen town, Germany, where von Froelich is known to have studied, lived and worked, when he made the original description of $E$. revolutum (see Enigk, 1986). To obtain cercariae the snails were separated individually in Petri dishes and stimulated with light. Tails and fin folds were studied in living cercariae stained using $0.5 \%$ neutral red solution diluted to half-strength with physiological saline, and in cercariae fixed in either $5 \%$ hot formalin or $2 \%$ silver nitrate solution. Photomicrographs and drawings were made using light microscope «Opton " equipped with phase contrast illumination, automatic photocamera, camera lucida and videomat. At last 500 specimens were examined and measured. All measurements are in micrometers.

\section{RESULTS}

Cercariae of $E$. revolutum possess long cylindrical tails, which are wider in the proximal end, near the body junction, and narrow distally. The tails range from 400 to 600 in length and 40 to 60 in width. The shape of the tail varies from straight to slightly curved. The tips are cons- 


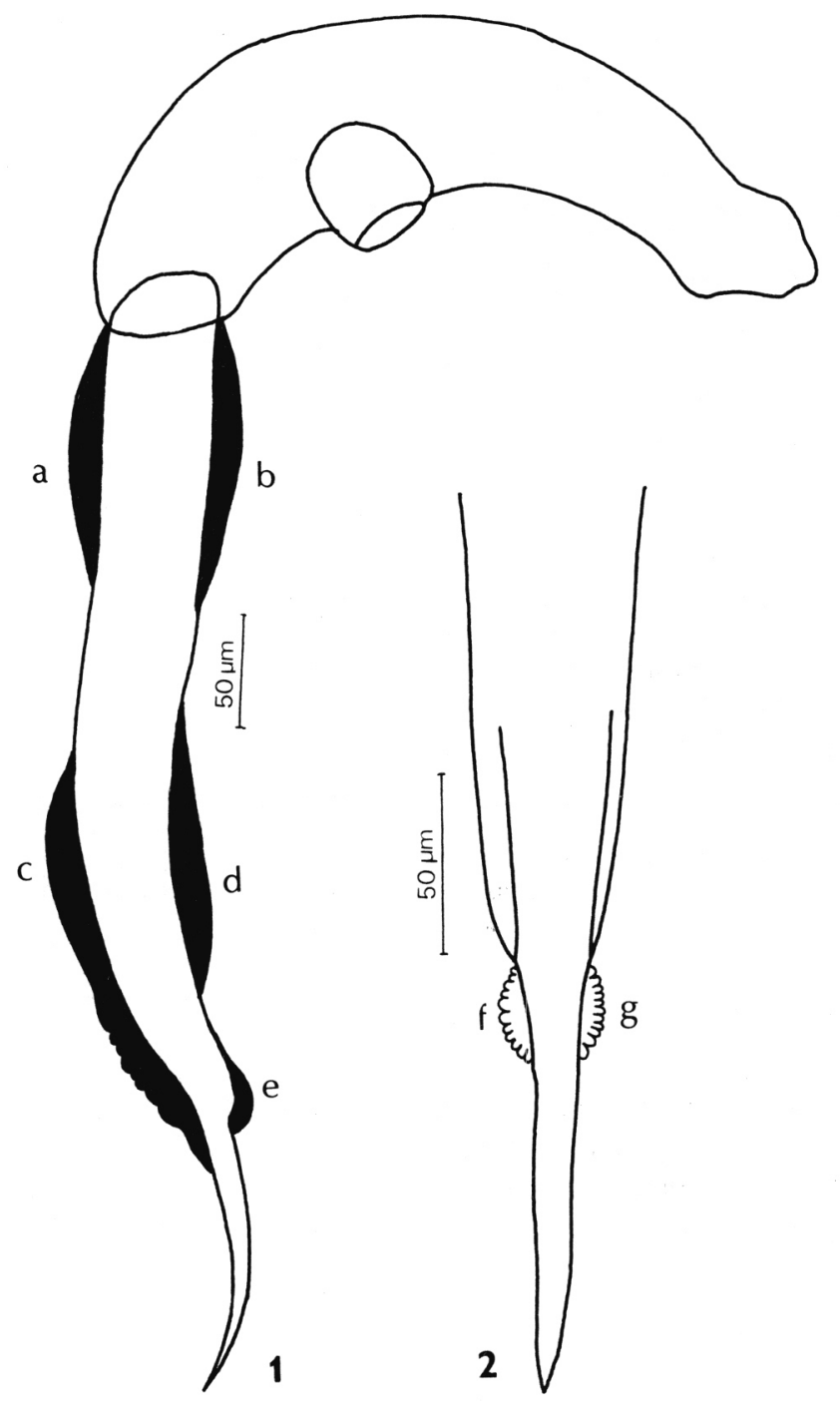

Figs. 1, 2. - Echinostoma revolutum cercariae. 1. Cercaria in lateral view showing: proximal dorsal fold $(a)$ and proximal vetral fold $(b)$ of the proximal dorso-ventral pair; distal dorsal $(c)$ and distal ventral folds $(d)$ of the distal dorso-ventral pair; and papilla-like fold $(e)$. 2. Cercarial tail in ventral view showing a pair of small ventro-lateral fin folds on the right $(f)$ and on the left $(g)$ side of the tail. Camera lucida drawings. Scale bars $=50 \mu \mathrm{m}$.

tricted unilateral ventrally with a typical slender finger-like projection (Figs. 1, 2).

Seven independent fin folds are arranged regularly on the tail surface (Fig. 1, 2). Three ventral, two dorsal, and two ventro-lateral. Six of the fin folds are arranged in three pairs: one proximal dorso-ventral pair with two developed folds begining at the body-tail junction, with the dorsal fold generally being shorter 70 to 100 long and 5 to 10 wide. The opposite ventral fold is 100 to 130 long and 5 to 10 wide, and further posterior. The second distal dorso-ventral pair has two large fin folds, the ventral fold is 100 to 130 long and 7 to 15 wide, usually begining and ending more proximally than the opposite dorsal fold. The last fold is large, 150 to 190 long and 10 to 20 wide, and extends further posterior than the second. The third, ventro-lateral pair has two delicate fin folds, 40 to 50 in length which are bilaterally symmetrical and start near the level of the distal end of the ventral fold of the distal dorso-ventral pair, and end near the slender finger-like constriction of the tail tip. A single papilla-like fold is found on the ventral surface of the tail where it goes into a slender fingerlike process.

\section{DISCUSSION}

From its type locality, cercariae of E. revolutum possess seven fin folds, situated on a cylindrical tail with a slender finger-like tip. These structures could only be seen when cercariae were fixed in $5 \%$ hot formalin, and oriented in a position providing lateral view. Other fixation and examining techniques caused the fin folds remain partly or completely invisible. This may account for the failure to mentione, illustrate or completely describe these structures in the previous studies.

It appears that in previous reports, other echinostome cercariae were erroneously presented as E. revolutum. For example, Johnson (1920), Beaver (1937), Moravec et al. (1974), and Nasincova (1986) reported various genera and species including Echinostoma echinatum (Zeder, 1803), E. trivolvis (Cort, 1914), E. jurini (Skwortzow, 1924), and Echinoparyphium sp. of Johnson (1920) as E. revolutum. Detailed information regarding these taxonomic errors were presented by Kanev (1985). Most taxonomic errors were a result of inadequate examination of the fin fold structure. For example, several more fin folds were found on the tail surface of the same 37-collar spined cercaria from the USA which Beaver (1937) described and illustrated to possess only one fold (Kanev and Fried, 1983; Kanev, 1985; Fried and Fujino, 1987; Huffman and Fried, 1990). In other studies more fin folds have been found for cercariae from Europe and Africa (Kanev and Odening, 1983; Kanev, 1985). The same cercariae were reported by Odening (1962), Kosupko (1972), and Moravec et al. (1974) to possess two or four fin folds perspectively.

Lie and Umathevy (1965) described Echonostoma audyi sp. nov from Malaysia, as possessing six fin folds. Later the same echinostomes were re-examined by Lie and Kanev (1983), and found to be identical with E. audyi from Europe (=E. revolutum Froelich, 1802) (see Kanev, 1985). The same paper (Kanev, 1985) presented numerous photomicrographs, and drawins showing seven fin folds in cercariae obtained from different freshwater snails collected in Bulgaria, Poland, Czechoslovakia, Germany, Austria, England, USA, Vietnam, Georgia, Egypt and Brazil. However, at that time it was suggested that the small papilla-like fin fold is not an independent fold but rather 
a prolonged portion of the large ventral fold to the distal dorso-ventral pair. Therefor the total number of the fin folds was presented as six instead of seven. Nasincova (1986) and Zdarska et al. (1989) found through SEM and TEM studies the small papilla-like fold to be independent. Although they reported their specimens to be cercariae of $E$. revolutum, the specimens were obtained from the same snail host and collected in the same localities in Czechoslovakia from which Vassilev et al. (1982) described as Cercaria spinifera La Valette, 1855 = Echinostoma lindoense Sandground et Bonne, 1940, and which Kanev (1985) declared a junior synonym of Echinostoma echinatum (Zeder, 1803). Thus, the authors believed that the specimens examined by Nasincova (1986) and Zdarska et al. (1989) were not members of the species E. revolutum.

The exact function of the fin folds is unknown. Most probably the large dorso-ventral fin folds from the proximal and distal pairs are concerned with swimming. The small ventro-lateral and the single papilla-like folds are probably sensory in function. Observations with the stereomicroscope show that cercariae, when settled on the snail body, drag their tails to retain contact in the regions, where these three folds are located.

Acknowledgments. - This work was supported by research grants from the Bulgarian Academy of Sciences; Fund Scientific Investigations; grant Nr NI B-231; National Academic Foundation; Private Company "Vediza »; Research Cooperahou Conicet (Argentine Research Council) DT-6, Germany; University of Erlangen, Germany; Exchange visitors agreement between Spanish Research Council, and the Bulgarian Academy of Sciences; Holiday Travel Service, USA; and William C. Campbell Endowment Fund at the Harold W. Manter Laboratory of Parasitology, USA. Thanks are given to Mrs I. PetKova and Mrs E. KazANDJIEVA for their excellent technical assistance. We are grateful to $\mathrm{Pr}^{\mathrm{r}}$ M. H. Pritchard, $\mathrm{P}^{\mathrm{r}}$ B. Fried, $\mathrm{P}^{\mathrm{r}}$ C. ARMe, $\mathrm{D}^{\mathrm{r}}$ A. McCarthy, M. P. Olson AND M. D RICHARDSON for their critical reading of the manuscript.

\section{REFERENCES}

Balusek J., Vojtek J. : Prispevek k poznani nasich cerkarii. Folia Fac. Sci. Nat. Univ. Purkianae, Brun, 1973, 40, 3-43.

Beaver P. : Experimental studies on Echinostoma revolutum (Froelich), a fluke from birds and mammals. Ill. Biol. Monographs, $1937,15,11-96$.
Enigk K. : Geschichte der Helminthologie im deutschsprachigen Raum. Gustav Fischer Verlag, Stuttgart, 1986, 291-292.

Fried B., Fujino J. : Argentophilic and scanning electronmicroscopic observations of the tegumentary papillae of Echinostoma revolutum (Trematoda) cercariae. J. Parasitol., 1987, 73, 1169-1174.

Huffman J. E., Fried B. : Echinostoma and echinostomiasis. $A d v$. Parasitol., 1990, 30, 215-269.

Johnson J. C. : The life cycle of Echinostoma revolutum (Froelich). Univ. California Pub., Zool., 1920, 19, 335-388.

Kanev I : On the morphology, biology, ecology and taxonomy of Echinostoma revolutum group (Trematoda: Echinostomatidae: Echinostoma). Dr. Sci. Thesis, Bul. Acad. Sci., Sofia, 1985, 497 pp. (In Bulgarian with English summary).

Kanev I., Fried B. : Further studies on Cercaria echinostoma revolutum of Beaver (1937) (Trematoda: Echinostomatidae). Khelminthol. (Sofia), 1982, 16, 44-52.

Kanev I., Odening K. : Further studies on Cercaria spinifera La Valette, 1855 in Central Europe. Khelminthol. (Sofia), 1983, 15, 24-34 (In Bulgarian with English summary).

Kosupko G. A. : Studies on the morphology and biology of Echinostoma revolutum (Froelich, 1802) and E. miyagawai Ishii, 1932 (Trematoda: Echinostomatidae) on experimental material. Ph. D. Thesis, Vigis, Moskow, 1972, 195 pp. (In Russian).

Lie K. J., Kanev I. : Identification and distribution of Echinostoma lindoense, Echinostoma audyi and Echinostoma revolutum (Trematoda: Echinostomatidae). Z. Parasitenk., 1983, 69, 223-227.

Lie K. J., Umathevy T. : Studies on Echonostomatidae (Trematoda) in Malaya. VIII. The life history of Echonostoma audyi sp. n. J. Parasitol., 1965, 51, 781-788.

Moravec F., Barus V., Rysavy B., Yousuf F. : Observations on the development of two echinostomes: Echinoparyphium recurvatum and Echinostoma revolutum, the antagonist of human schistosomes in Egypt. Folia Parasitol. (Praha), 1974, 21, 107-126.

Nasincova V. : Contribution to the distribution and the life history of Echonostoma revolutum (Trematoda) in Central Europe. Vest. Cs. Spol. Zoll., 1986, 50, 70-80.

Odening K. : What is Cercaria spinifera La Valette? Some remarks on the species identity and biology of some echinostome cercariae. In : "Parasitic Worms and Aquatic Conditions », Proc. Symposium, Prague, 1964, 91-97.

Vassilev I., Kanev I., Swietlikowski M., Busta J. : Establishment of an echinostome with the features of Echinostoma lindoense Sandground et Bonne, 1940 (Echinostomatidae : Tremoda) in Poland and Czechoslovakia. Khelminthol. (Sofia), 1982, 13, 12-21 (In Bulgarian with English summary).

Zdarska Z. : Larvalni stadia motolic $\mathrm{z}$ vodnich plzu nauzemi CSSR. Cs. Parasitol., 1963, 10, 207-262.

Zdarska Z., Nasincova V., Valkounova J. : Ultrastructure of the tail of Echinostoma revolutum cercaria. Folia Parasitol. (Praha), 1989, 36, 239-242. 